\title{
PENILAIAN KONDISI TINGGALAN BUDAYA MARITIM DALAM KEGIATAN PRA-KONSERVASI DI DERMAGA WILLUNGA
}

\section{CONDITIONS ASSESSMENT OF MARITIME CULTURAL HERITAGE IN PRE-CONSERVATION ACTIVITIES AT PORT WILLUNGA JETTY}

\author{
Ashar Murdihastomo' dan Rizka Purnamasari² \\ Pusat Penelitian Arkeologi Nasional', Balai Arkeologi Yogyakarta² \\ ashar.murdihastomo@kemdikbud.go.id'
}

\begin{abstract}
ABSTRAK
Bekas dermaga Willunga merupakan tinggalan budaya yang penting bagi masyarakat di Australia Selatan mengingat memiliki peran krusial dalam perekonomian daerah. Objek tinggalan budaya tersebut pada saat ini hanya tinggal bekas tiang penyangga dermaga dan perlu untuk dijaga kelestariannya mengingat lokasi dermaga pada saat ini telah menjadi salah satu daerah tujuan wisata yang dapat memberikan dampak buruk bagi keberlanjutan tinggalan budaya. Oleh karena itu, salah satu upaya yang dilakukan dalam melindungi objek tersebut adalah dengan melakukan upaya konservasi yang didahului oleh aktivitas pra-konservasi yaitu penilaian kondisi objek. Terkait dengan hal tersebut, maka permasalahan yang diangkat pada artikel ini adalah sejauh mana kondisi tinggalan budaya bekas dermaga di Willunga berdasarkan pada penilaian kondisi pra-konservasi. Tujuan dari penulisan artikel ini adalah memberikan gambaran lengkap tentang penanganan tinggalan budaya dan langkah-langkah yang ditempuh dalam kegiatan konservasi khususnya aktivitas pra-konservasi. Dalam upaya menjawab pertanyaan tersebut dilakukan pengambilan data melalui beberapa alat. Pertama, pengambilan data lingkungan menggunakan datalogger, pengambilan data pelapukan kayu melalui alat pilodyn, dan pengambilan data korosi besi menggunakan $\mathrm{pH}$ dan Eh meter. Kedua, data yang sudah diperoleh kemudian dianalisis menggunakan bantuan dari data sekunder (pustaka) dan penggunaan diagram dan tabel pourbaix. Hasil yang diperoleh dari kajian tersebut menyimpulkan bahwa kondisi tinggalan budaya di bekas dermaga Willunga mengalami degradasi yang diakibatkan oleh faktor lingkungan. Hasil tersebut kemudian dapat dijadikan acuan dalam melakukan aktivitas konservasi aktif.
\end{abstract}

Kata Kunci: Tinggalan maritim; penilaian pra-- konservasi; dermaga Willunga; konservasi aktif

\section{ABSTRACT}

The former Willunga jetty is an important cultural object for people in South Australia given its crucial role in the regional economy. The object of the cultural heritage at this time is only a pole and needs to be preserved because the location of the object has become one of the tourist destinations that can harm the sustainability of the object. Therefore, one of the efforts made to protect the object is to carry out conservation efforts that are preceded by pre-conservation activities, namely the assessment of the condition of the object. The problem raised in this article is the extent to which the cultural condition of the former jetty in Willunga is based on an assessment of preconservation conditions. The purpose is to provide a complete picture of handling cultural heritage and the steps taken in conservation activities, especially pre-conservation activities. To answer these questions, we did some steps. First, the collection of environmental data using a datalogger, wood weathering data retrieval via a pilodyn tool, and retrieval of iron corrosion data using $\mathrm{pH}$ and Eh meters. Second, the data that has been obtained is then analyzed using the help of secondary data (literature), the use of pourbaix diagrams, and tables. The results said that the condition of the cultural heritage at the former Willunga pier has experienced degradation due to environmental factors. The results are then used as a reference in conducting active conservation activities.

Keywords: Maritime heritage; pre-conservation assessment, Willunga jetty, active conservation 


\section{PENDAHULUAN}

Tinggalan budaya merupakan segala sesuatu yang menjadi hasil dari aktivitas manusia yang kemudian menjadi bagian dari suatu masyarakat (Yondri, Lubis dan Mundardjito 2016, 140). Tinggalan budaya ini adalah bentuk adaptasi masyarakat terhadap lingkungannya atau juga dapat berupa hasil pemahaman masyarakat terhadap fenomena yang terjadi di sekelilingnya dan pada akhirnya hasil budaya tersebut diturunkan kepada generasi berikutnya. Tinggalan budaya tersebut memiliki sifat dinamis, artinya dapat berkembang sesuai dengan kondisi masyarakat, bahkan juga dapat rusak atau hilang apabila tidak ada lagi masyarakat yang mendukungnya (Rosana 2017, 24).

Pada kondisi tersebut, ilmu arkeologi menjadi salah satu kajian yang berusaha untuk mempertahankan keberadaan tinggalan budaya masa lalu, baik yang sudah tidak memiliki masyarakat pendukungnya maupun yang hanya tinggal segelintir orang saja. Tujuannya yang ingin dicapai adalah melindungi dan melestarikan tinggalan budaya tersebut agar masyarakat pada saat ini mampu mengambil nilai positifnya, seperti menjadikannya identitas masyarakat, meningkatkan perekonomian masyarakat melalui wisata dan lainnya, serta dapat dijadikan sebagai objek pembelajaran (Suantika 2007, 16; Astiti 2016, 23 dan 27).

Perlindungan dan pelestarian terhadap tinggalan budaya tersebut dilakukan karena adanya beberapa pertimbangan. Pertama adalah sifatnya yang rapuh, unik, terbatas, tidak dapat diperbaharui dan tidak bisa digantikan. Kedua, kondisi lingkungan sekitar yang mampu mempengaruhi kondisi tinggalan budaya, seperti iklim, cuaca, kondisi alam, hingga manusia. Ketiga, perkembangan dan kebijakan pemerintah mampu memberikan pengaruh besar dalam pelestarian dan pengelolaan tinggalan budaya. Melalui ketiga pertimbangan tersebut diharapkan dapat tercapai perlindungan dan pelestarian tinggalan budaya yang maksimal (Dillenia dan Kusuma 2009, 81; Rahardjo 2013, 5 dan 10).

Salah satu aspek yang sangat penting dalam proses perlindungan dan pelestarian tinggalan budaya adalah melalui kegiatan konservasi. Secara umum, aktivitas konservasi merupakan suatu kegiatan sistematis berupa langkah-langkah spesifik, prinsip, sistem teknik dan metode yang disesuaikan kepada objeknya (E.C.C.O, 2008 dalam Spiridona dan Sandu 2015, 44). Aktivitas konservasi ini dilakukan sebagai upaya perlindungan tinggalan budaya yang bertujuan agar tinggalan tersebut dapat bertahan lama. Konservasi terhadap tinggalan budaya ini menjadi salah satu tema yang cukup populer di kalangan pegiat tinggalan budaya di seluruh dunia mengingat perkembangan ilmu mampu memberikan pengembangan terhadap proses konservasi.

Konservasi terhadap benda tinggalan budaya tidak hanya dilakukan pada objek yang berada di darat namun juga dilakukan pada objek yang berada di daerah perairan. Objek tersebut sering dikaitkan dengan aktivitas kemaritiman sehingga kemudian disebut dengan tinggalan budaya maritim. Prinsip konservasi yang diterapkan pada objek budaya ini memiliki penekanan yang sama dengan konservasi pada tinggalan budaya yang ada di darat, yaitu melakukan perlindungan agar tinggalan budaya tersebut dapat bertahan lebih lama.

Konservasi tinggalan budaya maritim ini menjadi salah satu fokus kegiatan yang dilakukan oleh Departemen Maritim, Universitas Flinders, Adelaide, Australia Selatan yang merupakan salah satu instansi akademik yang berfokus pada aktivitas kemaritiman. Pada kesempatan ini, penulis mencoba memaparkan hasil dari keikutsertaan dalam kegiatan prakonservasi di instansi tersebut ke suatu artikel ilmiah sebagai upaya mengenalkan salah satu proses kegiatan konservasi tinggalan budaya maritim.

Departemen Maritim, Universitas Flinders melakukan kegiatan penilaian kondisi tinggalan budaya di bekas dermaga daerah Willunga. Objek yang masih tersisa di daerah tersebut adalah beberapa tiang dermaga dan gua buatan. Bagi masyarakat Australia pada umumnya dan masyarakat Wilunga pada khususnya, tinggalan budaya ini merupakan objek 
penting mengingat memiliki peran krusial dalam perekonomian daerah. Pertanian dan peternakan telah dimulai dari tahun 1839 hingga sekarang. Dalam mendukung aktivitas di kedua sektor tersebut maka dibangunlah beberapa fasilitas yang salah satunya adalah dermaga (McDougall dan Vines 1997, 7-10),

Mark Staniforth (2016) melalui paparannya menyebutkan bahwa terdapat dua dermaga yang ada di Willunga. Dermaga tersebut berfungsi sebagai sistem transportasi di daerah tersebut untuk memasok dan mengirimkan barang-barang ekonomis kebutuhan masyarakat. Dermaga pertama dibangun dari tahun 1853 dan selesai pada tahun 1857 dengan panjang dermaga sekitar $145 \mathrm{~m}$ di sisi sebelah utara. Dermaga kedua didirikan di sebelah selatan pada tahun 1867 dan selesai pada tahun 1868. Dermaga ini berbeda dengan dermaga pertama karena memiliki kelengkapan sistem rel dan pengungkit (crane) (Gambar 1). Penggunaan fasilitasi tersebut menempatkan dermaga kedua ini untuk aktivitas ekspor atas hasil pertanian dari lembah McLaren. Namun, lambat laun kondisi kedua dermaga di atas rusak dan hancur akibat dari perang dunia kedua.

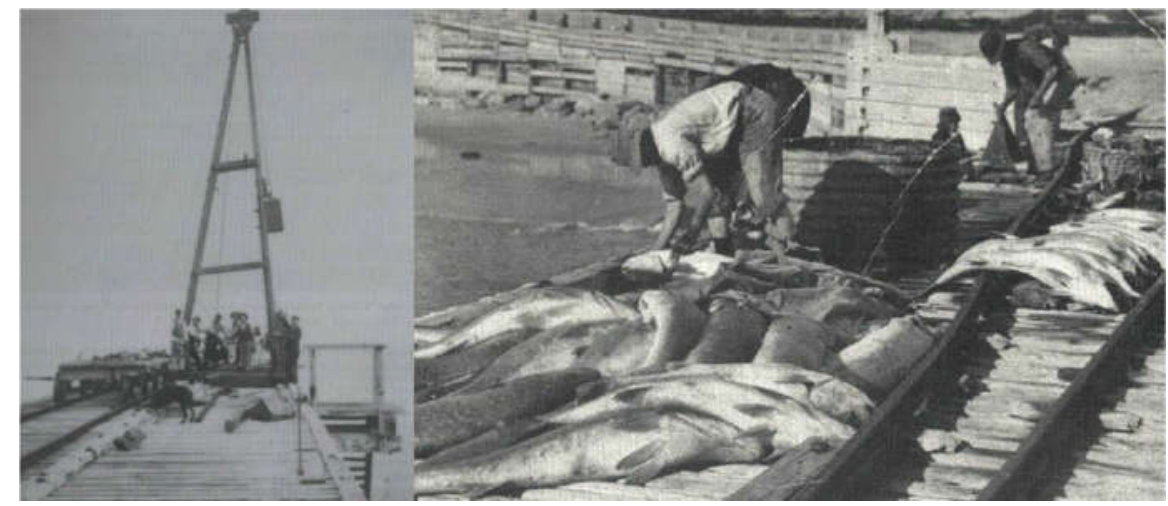

Gambar 1. Penampakan Aktivitas Masyarakat Di Dermaga Kedua Willunga (Sumber: Mark Staniforth, 2016)

Pada saat ini, dermaga kedua hanya tersisa bekas tiang dermaga saja yang berjumlah sekitar 47 tiang dalam berbagai kondisi. Area sekitarnya telah dimanfaatkan masyarakat sebagai tempat wisata pantai. Tiang dermaga ini bukan satu-satunya tinggalan yang dijumpai di Willunga. Terdapat tinggalan lainnya berupa gua yang dahulu sering dimanfaatkan oleh para nelayan. Terdapat paling tidak enam gua yang berbentuk persegi. Luas gua tiap-tiap gua berbeda satu sama lain namun diperkirakan $9 \mathrm{~m}^{2}$.
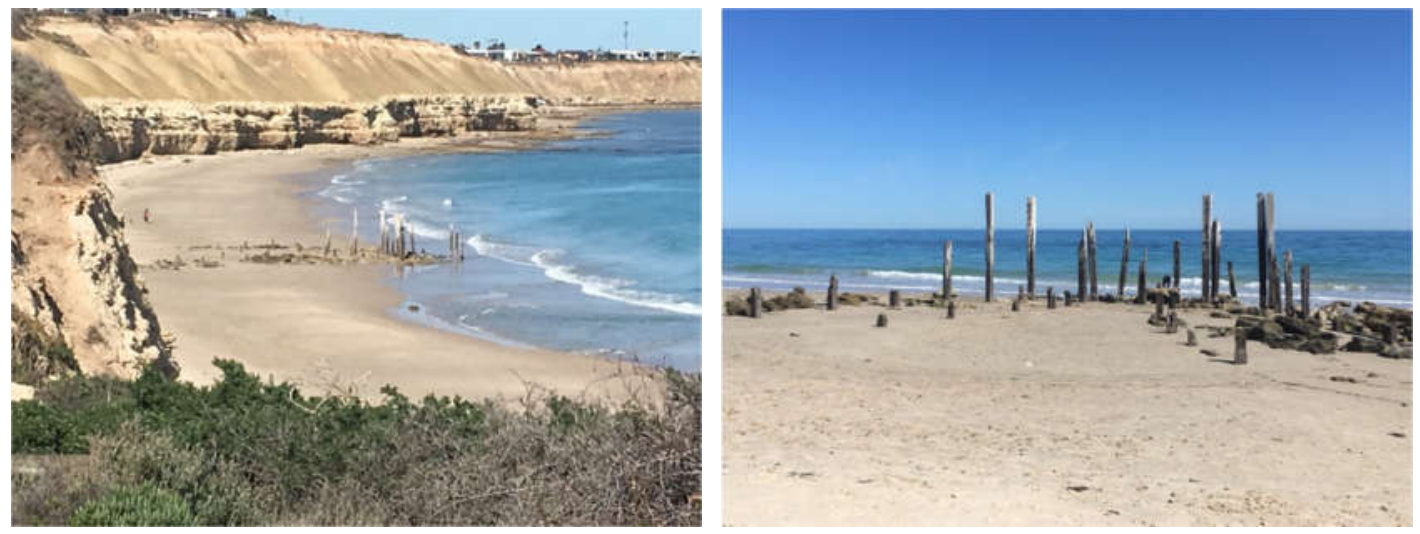

Gambar 2. Kondisi Dermaga Willunga Saat Ini

(Sumber: Christina Peters-Luster dan Julia Atkinson, 2019) 


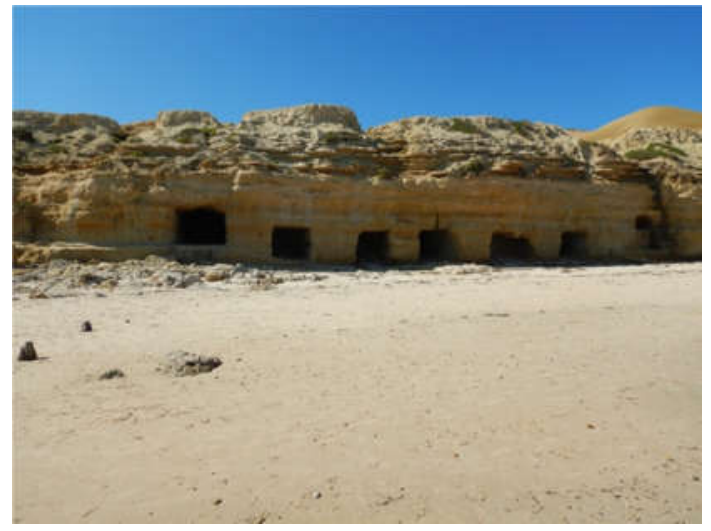

Gambar 3. Gua di Dekat Dermaga Willunga (Sumber: Jon Carpenter, 2019)

Objek tinggalan budaya tersebut perlu untuk dijaga kelestariannya mengingat lokasi dermaga pada saat ini telah menjadi salah satu daerah tujuan wisata yang dapat memberikan dampak buruk bagi keberlanjutan tinggalan budaya. Salah satu upaya yang dilakukan dalam melindungi objek tersebut adalah dengan melakukan upaya konservasi yang didahului oleh aktivitas pra-konservasi yaitu penilaian kondisi objek. Berdasarkan pada pernyataan tersebut, maka pada kesempatan ini penulis mengangkat pertanyaan sebagai berikut, Bagaimana kondisi tinggalan budaya bekas dermaga di Willunga. Melalui pertanyaan yang diajukan, tujuan dari penulisan artikel ini adalah memberikan gambaran lengkap tentang penanganan tinggalan budaya dan langkah-langkah yang ditempuh dalam kegiatan konservasi khususnya aktivitas pra-konservasi.

Kegiatan konservasi tinggalan budaya maritim memiliki proses yang berbeda dengan aktivitas konservasi pada umumnya. Hal ini dikarenakan banyaknya aspek yang perlu diperhatikan. Aspek-aspek tersebut saling berkaitan satu sama lain sehingga tidak mungkin dapat dipisahkan. Apabila ada beberapa aspek yang terlewatkan maka aktivitas konservasi tidak dapat dilakukan secara optimal. Oleh karena itu, kegiatan konservasi pada tinggalan budaya maritim didahului oleh kegiatan penilaian kondisi.

Florian (1987, 1-20) menyatakan bahwa kegiatan konservasi tinggalan budaya maritim harus didahului dengan observasi terhadap dua hal, yaitu lingkungan perairan dan material dari tinggalan budaya tersebut. Pemahaman terhadap lingkungan perairan laut merupakan salah satu pengetahuan yang harus dimiliki oleh para pegiat konservasi tinggalan budaya maritim. Pemahaman terhadap aspek ini digunakan untuk mengetahui interaksi antara aspek kimia, fisik, dan biologi dengan aspek material dari tinggalan budaya tersebut. Dengan mempelajari aspek ini maka akan muncul suatu pertimbangan terkait dengan sifat dari air laut, sifat sedimen, sifat dari biota air, klasifikasi area perairan tempat tinggalan budaya tersebut, dan klasifikasi keberadaan objek. Hal ini karena kelimanya merupakan penyebab dari kerusakan (deterioration) kondisi dari tinggalan budaya maritim yang ada di perairan. Penjelasan dari ketiga sifat tersebut dapat dilihat di bawah ini:

1. Sifat air laut

Air laut memiliki sifat yang berbeda-beda tergantung dari lokasinya. Perbedaan tersebut antara lain adalah unsur pelarut, unsur kimia, kadar garam, keberadaan gas, kadar alkali, sistem penyangga, oksidasi dan reduksi, serta penguapan. 


\section{Sifat sedimen}

Sedimen terbentuk dari adanya pergerakan material organik dan anorganik yang masuk ke wilayah perairan. Aspek sedimen ini akan berkaitan erat dengan asal sedimen, karakteristik fisiknya, kimianya, komposisi pengantara, proses diagenesis, daya larut, dan mekanisme transportasi.

3. Sifat biota air

Air merupakan salah satu lokasi tempat tinggal para binatang dan tumbuhan. Beragamnya jenis binatang dan tumbuhan dapat berdampak pada kondisi lingkungan perairan. Hal tersebut antara lain adalah klasifikasi zona perairan, kumpulan fouling, jamur dan moluska, bakteri perairan,

4. Klasifikasi area perairan

Area perairan maritim, khususnya laut, memiliki beberapa zona yang dibedakan berdasarkan kedalaman, yaitu supratidal (supralittorah), litoral (Iittora), neritic (sublittorah), laut dalam (bathyah), dasar samudera (abyssah), dan hadal. Perbedaan zona tersebut memberikan pengaruh terhadap besar-kecilnya tekanan yang diterima oleh tinggalan budaya.

5. Klasifikasi posisi tinggalan budaya

Klasifikasi ini terkait dengan posisi tinggalan budaya yang berada di perairan. Tinggalan budaya tersebut dapat ditemukan dalam posisi setengah terendam air, seluruhnya terendam air, setengah terpendam, dan seluruhnya terpendam. Posisi ini memberikan pengaruh terhadap kondisi material penyusun artefak tersebut

Sementara itu, material menjadi salah satu aspek dalam kegiatan konservasi yang perlu untuk diperhatikan. Beberapa material yang menjadi bahan dasar dalam pembuatan benda tinggalan budaya adalah material organik dan anorganik, antara lain kayu, kulit, kertas, logam, hingga keramik. Material-material tersebut tersusun dalam komposisi kimia, biologi, dan fisik yang berbeda. Hal tersebut menyebabkan adanya perbedaan dalam beberapa hal, antara lain perbedaan penyebab kerusakan, perbedaan kecepatan dalam proses kerusakan, dan perbedaan penanganan.

Proses konservasi tinggalan budaya maritim telah dilakukan oleh beberapa akademisi. Dillenia dan Kusuma (2009) menyatakan bahwa terdapat peluang dan tantangan bagi pemerintah Indonesia untuk melakukan perlindungan sumber daya arkeologi bawah air terutama dengan mulai berkembangnya perlindungan in-situ. Peluang yang dimiliki oleh pemerintah Indonesia adalah banyaknya sumber daya arkeologi bawah air yang ada di perairan Indonesia, sedangkan tantangan yang dihadapi adalah belum tertanganinya sumber daya arkeologi tersebut secara optimal.

Julianto dan Sulaiman (2015) telah melakukan kajian dalam melakukan perlindungan in-situ di salah satu cagar budaya tinggalan bawah air berupa kapal karam di Indonoer. Perlindungan in-situ yang dimaksud adalah dengan melakukan perlindungan katodik dengan tumbal anoda untuk kebutuhan proteksi terhadap material kapal karam. Hasil kajian menunjukkan bahwa perlindungan katodik berpotensi dikembangkan dalam pelestarian cagar budaya bawah air.

Mochtar (2016) melihat bahwa signifikansi keberadaan peninggalan arkeologi bawah air di Indonesia menunjukkan betapa pentingnya pelestarian peninggalan tersebut. Dalam kajian yang dilakukan oleh Mochtar, kondisi di Indonesia masih menunjukkan 
adanya kontradiksi antara aspek ekonomi dengan aspek perlindungan. Oleh karena itu, perlu dilakukan kajian ulang terhadap kebijakan dan regulasi pada peninggalan bawah air dengan menekankan pada aspek perlindungan, salah satunya adalah perlindungan in-situ.

Hidayat (2018) mencoba melihat aspek konservasi peninggalan bawah air melalui sisi praktisnya. Hidayat berfokus pada proses konservasi artefak logam tembaga yang telah diangkat dari lingkungan air. Proses konservasi yang dimaksud dalam kajiannya adalah menghilangkan korosi dan patina yang melekat pada artefak logam tembaga menggunakan larutan $5 \% \mathrm{Na}_{2} \mathrm{CO}_{3}$ dengan $\mathrm{pH} 11-13$, serta pelapisan dengan pasta natrium bikarbonat dan air jeruk nipis.

Berdasarkan pada beberapa kajian tersebut diketahui bahwa aspek konservasi tinggalan budaya maritim (salah satunya adalah bawah air) masuk dalam dua aspek, yaitu teoritis dan praktis. Aspek teoritis berusaha menunjukkan urgensi dari perlindungan in-situ pada tinggalan maritim, sedangkan aspek praktis mencoba untuk menunjukkan proses perlindungan tinggalan budaya. Pada aspek praktis menunjukkan bahwa aktivitas perlindungan dilakukan dalam konteks konservasi aktif. Sementara itu, aktivitas perlindungan dalam konteks pra-konservasi aktif belum terlihat. Oleh karena itu, artikel ini akan berfokus pada aktivitas pra-konservasi.

\section{METODE}

Kegiatan penilaian kondisi dilakukan dengan menggunakan beberapa peralatan ukur yang telah dikenal dalam aktivitas sains. Peralatan itu terdiri atas pengukur kadar oksigen, pengukur tingkat keasaman, pengukur suhu, pengukur kadar salinitas air, pengukur potensi redoks, dan alat untuk mengukur tingkat pelapukan. Keberadaan peralatan ini disesuaikan penggunaannya berdasarkan material yang dinilai.

Pengukuran kondisi perairan yang meliputi kondisi pelarutan oksigen, salinitas, dan temperatur sesuai dengan kedalaman dengan menggunakan datalogger. Cara menggunakan alat ini adalah dengan cara memasukkan ujung sensor dari datalogger ke dalam perairan dan ditunggu hingga data yang masuk ke datalogger telah berada pada kondisi stabil (angka tidak berubah). Pengambilan data menggunakan alat ini dilakukan sesuai dengan level kedalaman air. Pengujian dengan melakukan di kedalaman yang berbeda memiliki tujuan untuk mengetahui beberapa kondisi lingkungan yang ada di dalam perairan. Setidaknya dibutuhkan tiga sampai empat orang untuk melakukan pengambilan data ini, satu atau dua orang berada di air untuk melakukan pengukuran, sedangkan satu orang mengoperasikan datalogger sambil membaca data yang diperoleh, serta satu orang lainnya mencatat.

Pengukuran kondisi objek tinggalan budaya dilakukan pada material kayu dan besi. Pengukuran material kayu dilakukan menggunakan alat bernama pilodyn untuk mengetahui tingkat pelapukan kayu. Pilodyn merupakan suatu alat berbentuk tabung yang di bagian dalamnya terdapat pegas dan jarum. Ketika alat tersebut ditembakkan ke kayu, maka jarum akan masuk ke dalam kayu sesuai dengan tingkat pelapukannya.

Sementara itu, pengukuran material besi dilakukan dengan tiga buah alat, pertama alat bor yang digunakan untuk mengebor lapisan korosi pada besi kemudian hasil pengeboran ditempelkan sensor $\mathrm{pH}$ meter dilanjutkan dengan Eh meter. Sensor $\mathrm{pH}$ meter ini digunakan untuk mengetahui tingkat keasaman yang mempengaruhi proses korosi besi, sedangkan Eh meter untuk mengukur potensi redoks pada material besi.

Hasil akhir dari pengukuran yang telah dilakukan tersebut berupa angka. Angkaangka tersebut kemudian dijabarkan secara narasi dengan menggabungkan hasil 
pengumpulan data dengan kajian pustaka agar terlihat keterkaitan antara satu data dengan data lainnya. Selain itu, hasil pengukuran terhadap material besi dimasukkan ke dalam diagram pourbaix untuk mengetahui aktivitas korosi, apakah pasif atau aktif. Kemudian langkah terakhir adalah mengambil kesimpulan sebagai dasar untuk memilih dan melaksanakan konservasi aktif yang sesuai dengan kondisi tersebut.

\section{HASIL PENELITIAN}

\section{Hasil Penilaian Kondisi Tinggalan Budaya Dermaga Willunga}

Aktivitas penilaian dilakukan pada tiga aspek yaitu, kondisi untuk mengetahui kondisi lingkungan di sekitar tinggalan budaya, pengukuran pelapukan kayu, dan pengukuran korosi besi. Aktivitas penilaian ini dilakukan oleh dua tim yang bertujuan untuk menunjukkan perbandingan. Pembagian area masing-masing tim dapat dilihat pada Gambar 4. Hasil penilaian dapat dilihat pada bagian bawah berikut ini:

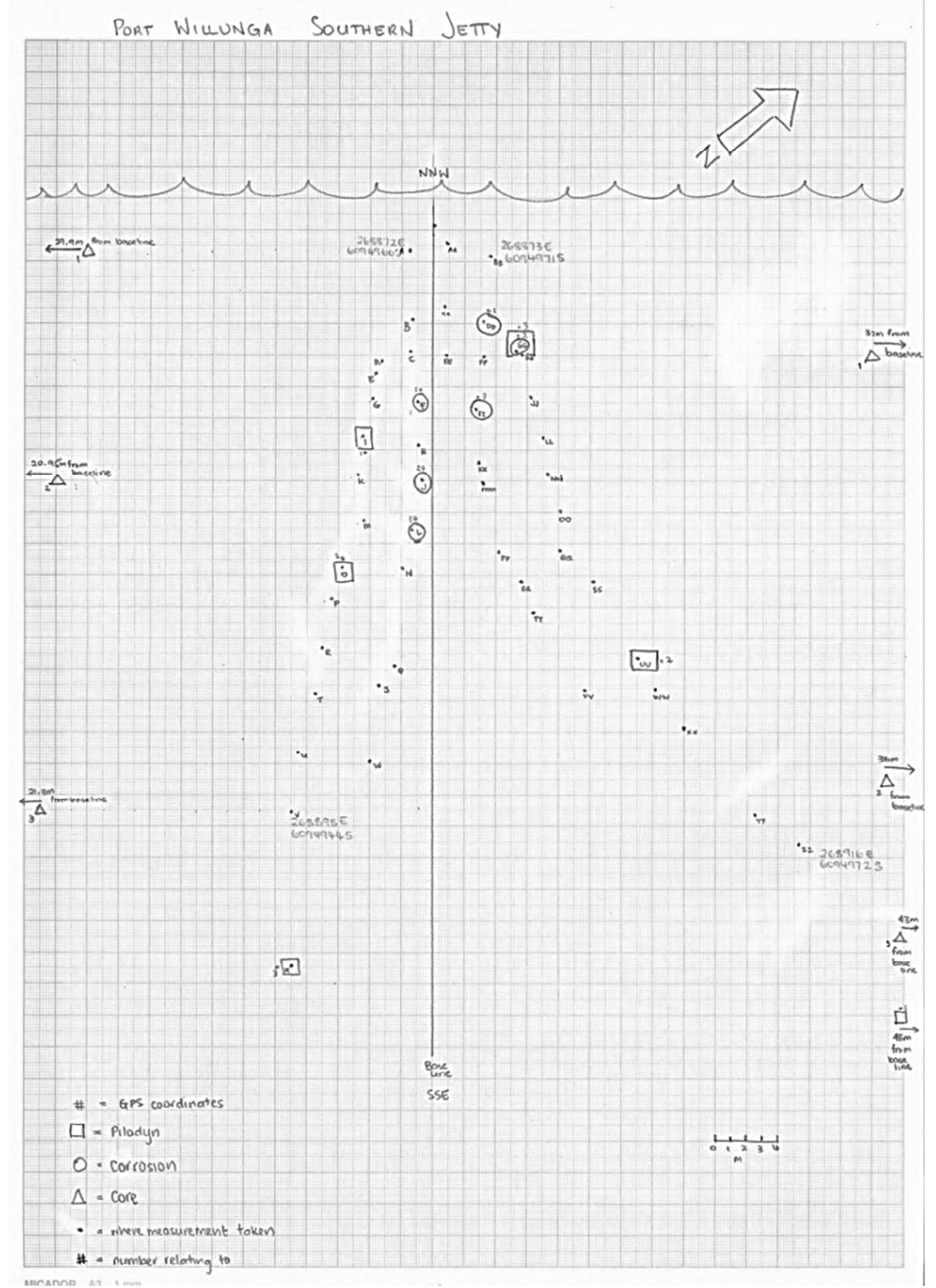

Gambar 4. Pembagian Area: Tim A di Sisi Kanan Baseline, sedangkan Tim B di Sisi Kiri Baseline (Sumber: Howard Boyle, 2019) 


\section{Hasil penilaian kondisi perairan}

Kondisi perairan yang menjadi tempat di mana sebuah tinggalan arkeologi berada sangat penting untuk diperiksa. Hal ini dilakukan untuk mengetahui sejauh mana sifat-sifat perairan ini akan mempengaruhi kelestarian tinggalan tersebut. Perbedaan sifat-sifat perairan akan mempengaruhi strategi dalam pelestarian, misalnya perlakuan pada tinggalan kapal tenggelam di Laut Baltik yang salinitasnya rendah dan bersuhu dingin akan berbeda dengan perairan tropis Indonesia yang kadar salinitasnya di ambang rata-rata.

Penilaian ini dilakukan dengan menggunakan alat bernama datalogger. Alat ini merekam beberapa hal, antara lain berupa, DO (Disolved Oxygen), pH, temperatur,

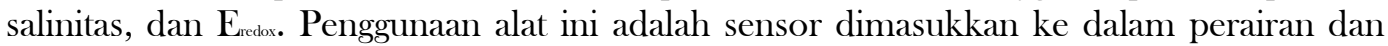
ditunggu hingga data yang masuk ke datalogger telah berada pada kondisi stabil (angka tidak berubah). Pengambilan data menggunakan alat ini dilakukan sesuai dengan level kedalaman air. Pengujian dengan melakukan di kedalaman yang berbeda memiliki tujuan untuk mengetahui beberapa kondisi lingkungan yang ada di dalam perairan.

Dalam kesempatan ini, kedua tim (Tim A dan Tim B) melakukan penilaian kondisi perairan di waktu yang berbeda. Tim A melakukan penilaian di waktu siang hari sementara tim B melakukan penilaian pada pagi hari. Perbedaan waktu pelaksanaan penilaian kondisi perairan ini dimaksudkan untuk melihat perbandingan kondisi di dua waktu. Perekaman data dilakukan dengan interval setiap $10 \mathrm{~cm}$ hingga mencapai kedalaman $900 \mathrm{~cm}$. Namun tidak semua data terekam pada setiap interval. Pada interval kedua atau $10 \mathrm{~cm}$, baik Tim A maupun Tim B agak kesusahan, terbukti adanya data yang tidak terekam. Hal ini diperkirakan karena adanya pengaruh gelombang air di permukaan yang menyebabkan sensor tidak dapat mengambil data secara akurat.

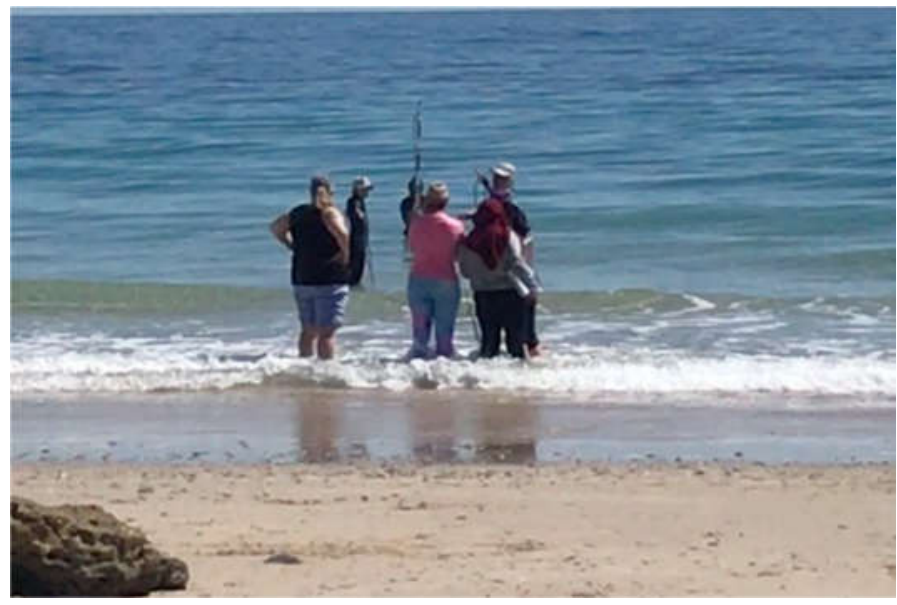

Gambar 5. Proses Penilaian Kondisi Perairan

(Sumber: Wendy Van Duivenvoorde, 2019)

- $\quad$ DO (Dissolved Oxygen)

DO merupakan istilah untuk menyebut jumlah oksigen yang larut dalam suatu lingkungan perairan. Kadar oksigen yang ada di lautan berasal dari penyerapan udara dari atmosfer, aktivitas makhluk hidup dan dekomposisi material organik oleh bakteri anaerobik. Daya pelarutan oksigen akan menurun seiring dengan naiknya suhu dan klorinitas (Florian 1987, 4).

DO merupakan istilah untuk menyebut jumlah oksigen yang larut dalam suatu lingkungan perairan. Hasil dari pengukuran DO oleh dua tim dapat dilihat pada tabel di bawah ini: 
Tabel 1. Hasil Pengukuran DO Tim A

\begin{tabular}{cc}
\hline $\begin{array}{c}\text { Kedalaman } \\
(\mathbf{m})\end{array}$ & $\begin{array}{c}\text { DO } \\
(\mathbf{p p m})\end{array}$ \\
\hline $\mathbf{0 , 0}$ & 8,47 \\
$\mathbf{0 , 1}$ & Tidak terekam \\
$\mathbf{0 , 2}$ & 8,33 \\
$\mathbf{0 , 3}$ & 8,35 \\
$\mathbf{0 , 4}$ & 8,67 \\
$\mathbf{0 , 5}$ & 8,63 \\
$\mathbf{0 , 6}$ & 8,37 \\
$\mathbf{0 , 7}$ & 8,56 \\
$\mathbf{0 , 8}$ & 8,66 \\
$\mathbf{0 , 9}$ & 8,83 \\
\hline Sumber: Data Tim A, 2019
\end{tabular}

- Derajat keasaman $(\mathrm{pH})$

Hasil pengukuran terhadap derajat keasaman yang ada di dermaga Willinga ini dapat dilihat pada tabel dibawah ini:

Tabel 3. Hasil Pengukuran Derajat Keasaman Tim A

\begin{tabular}{cc}
\hline $\begin{array}{c}\text { Kedalaman } \\
(\mathbf{m})\end{array}$ & $\mathbf{p H}$ \\
\hline $\mathbf{0 , 0}$ & 8,17 \\
$\mathbf{0 , 1}$ & Tidak terekam \\
$\mathbf{0 , 2}$ & 8,17 \\
$\mathbf{0 , 3}$ & 8,18 \\
$\mathbf{0 , 4}$ & 8,17 \\
$\mathbf{0 , 5}$ & 8,18 \\
$\mathbf{0 , 6}$ & 8,18 \\
$\mathbf{0 , 7}$ & 8,18 \\
$\mathbf{0 , 8}$ & 8,19 \\
$\mathbf{0 , 9}$ & 8,19 \\
\hline Sumber: Data Tim A, 2019
\end{tabular}

Tabel 2. Hasil Pengukuran DO Tim B

\begin{tabular}{cc}
\hline $\begin{array}{c}\text { Kedalaman } \\
(\mathbf{m})\end{array}$ & $\begin{array}{c}\mathbf{D O} \\
(\mathbf{p p m})\end{array}$ \\
\hline $\mathbf{0}$ & $8,14^{*}$ \\
$\mathbf{0 , 1}$ & Tidak terekam \\
$\mathbf{0 , 2}$ & 6,99 \\
$\mathbf{0 , 3}$ & 6,81 \\
$\mathbf{0 , 4}$ & 6,84 \\
$\mathbf{0 , 5}$ & 6,84 \\
$\mathbf{0 , 6}$ & 6,81 \\
$\mathbf{0 , 7}$ & 6,85 \\
$\mathbf{0 , 8}$ & 6,79 \\
$\mathbf{0 , 9}$ & 6,77 \\
\hline Sumber: Data Tim B, 2019
\end{tabular}

- Temperatur

Hasil pengukuran temperatur dapat dilihat pada tabel di bawah ini:

Tabel 5. Hasil Pengukuran Temperatur Tim A

\begin{tabular}{cc}
\hline $\begin{array}{c}\text { Kedalaman } \\
(\mathbf{m})\end{array}$ & $\begin{array}{c}\mathbf{T} \\
\left({ }^{\mathbf{O}} \mathbf{C}\right)\end{array}$ \\
\hline $\mathbf{0 , 0}$ & 17,2 \\
$\mathbf{0 , 1}$ & Tidak terekam \\
$\mathbf{0 , 2}$ & 17,3 \\
$\mathbf{0 , 3}$ & 16,9 \\
$\mathbf{0 , 4}$ & 16,9 \\
$\mathbf{0 , 5}$ & 17,0 \\
$\mathbf{0 , 6}$ & 16,8 \\
$\mathbf{0 , 7}$ & 16,6 \\
$\mathbf{0 , 8}$ & 16,4 \\
$\mathbf{0 , 9}$ & 16,2 \\
\hline Sumber: Data Tim A, 2019
\end{tabular}

- Salinitas
Tabel 4. Hasil Pengukuran Derajat Keasaman Tim B

\begin{tabular}{cc}
\hline $\begin{array}{c}\text { Kedalaman } \\
(\mathbf{m})\end{array}$ & $\mathbf{p H}$ \\
\hline $\mathbf{0}$ & 8,07 \\
$\mathbf{0 , 1}$ & 8,08 \\
$\mathbf{0 , 2}$ & 8,09 \\
$\mathbf{0 , 3}$ & 8,12 \\
$\mathbf{0 , 4}$ & 8,12 \\
$\mathbf{0 , 5}$ & 8,13 \\
$\mathbf{0 , 6}$ & 8,13 \\
$\mathbf{0 , 7}$ & 8,13 \\
$\mathbf{0 , 8}$ & 8,14 \\
$\mathbf{0 , 9}$ & 8,14 \\
\hline Sumber: Data Tim B 2019
\end{tabular}

Tabel 6. Hasil Pengukuran Temperatur Tim B

\begin{tabular}{cc}
\hline $\begin{array}{c}\text { Kedalaman } \\
(\mathbf{m})\end{array}$ & $\begin{array}{c}\mathbf{T} \\
\left({ }^{\mathbf{}} \mathbf{C}\right)\end{array}$ \\
\hline $\mathbf{0}$ & 15,6 \\
$\mathbf{0 , 1}$ & Tidak terekam \\
$\mathbf{0 , 2}$ & 15,6 \\
$\mathbf{0 , 3}$ & 15,8 \\
$\mathbf{0 , 4}$ & 15,6 \\
$\mathbf{0 , 5}$ & 15,6 \\
$\mathbf{0 , 6}$ & 15,5 \\
$\mathbf{0 , 7}$ & 15,6 \\
$\mathbf{0 , 8}$ & 15,6 \\
$\mathbf{0 , 9}$ & 15,6 \\
\hline Sumber: Data Tim B, 2019
\end{tabular}

Hasil dari pengukuran salinitas dapat dilihat pada tabel di bawah ini: 
Tabel 7. Hasil Pengukuran Salinitas Tim A

\begin{tabular}{cc|}
\hline $\begin{array}{c}\text { Kedalaman } \\
(\mathbf{m})\end{array}$ & $\begin{array}{c}\text { Sal } \\
\text { (ppt) }\end{array}$ \\
\hline $\mathbf{0 , 0}$ & 42,4 \\
$\mathbf{0 , 1}$ & Tidak terekam \\
$\mathbf{0 , 2}$ & 42,6 \\
$\mathbf{0 , 3}$ & 42,0 \\
$\mathbf{0 , 4}$ & 42,5 \\
$\mathbf{0 , 5}$ & 42,6 \\
$\mathbf{0 , 6}$ & 42,4 \\
$\mathbf{0 , 7}$ & 42,2 \\
$\mathbf{0 , 8}$ & 42,0 \\
$\mathbf{0 , 9}$ & 42,0 \\
\hline Sumber: Data Tim A, 2019
\end{tabular}

- $\mathrm{E}_{\text {redok }} /$ Redoks

Redoks merupakan proses penilaian terhadap kekuatan oksidasi dalam suatu lingkungan. Hasil dari pengukuran redoks dapat dilihat pada tabel di bawah ini:

Tabel 9. Tabel Pengukuran Potensi Oksidasi $\operatorname{Tim} \mathrm{A}$

\begin{tabular}{cc}
\hline $\begin{array}{c}\text { Kedalaman } \\
(\mathbf{m})\end{array}$ & $\begin{array}{c}\text { Redoks } \\
(\mathbf{V})\end{array}$ \\
\hline $\mathbf{0 , 0}$ & 0,311 \\
$\mathbf{0 , 1}$ & Tidak terekam \\
$\mathbf{0 , 2}$ & 0,302 \\
$\mathbf{0 , 3}$ & 0,302 \\
$\mathbf{0 , 4}$ & 0,302 \\
$\mathbf{0 , 5}$ & 0,302 \\
$\mathbf{0 , 6}$ & 0,302 \\
$\mathbf{0 , 7}$ & 0,302 \\
$\mathbf{0 , 8}$ & 0,302 \\
$\mathbf{0 , 9}$ & 0,301 \\
\hline Sumber: Data Tim A, 2019
\end{tabular}

Tabel 8. Hasil Pengukuran Salinitas Tim B

\begin{tabular}{cc}
\hline $\begin{array}{c}\text { Kedalaman } \\
(\mathbf{m})\end{array}$ & $\begin{array}{c}\text { Sal } \\
\text { (ppt) }\end{array}$ \\
\hline $\mathbf{0}$ & $23,5^{\star}$ \\
$\mathbf{0 , 1}$ & Tidak terekam \\
$\mathbf{0 , 2}$ & 42,4 \\
$\mathbf{0 , 3}$ & 42,4 \\
$\mathbf{0 , 4}$ & 42,5 \\
$\mathbf{0 , 5}$ & 42,4 \\
$\mathbf{0 , 6}$ & 42,4 \\
$\mathbf{0 , 7}$ & 42,5 \\
$\mathbf{0 , 8}$ & 42,5 \\
$\mathbf{0 , 9}$ & 42,4 \\
\hline
\end{tabular}

Sumber: Data Tim B, 2019
Tabel 10. Tabel Pengukuran Potensi Oksidasi Tim B

\begin{tabular}{cc}
\hline $\begin{array}{c}\text { Kedalaman } \\
(\mathbf{m})\end{array}$ & $\begin{array}{c}\text { Redoks } \\
\text { (V) }\end{array}$ \\
\hline $\mathbf{0 , 0}$ & 0,311 \\
$\mathbf{0 , 1}$ & 0,306 \\
$\mathbf{0 , 2}$ & 0,304 \\
$\mathbf{0 , 3}$ & 0,297 \\
$\mathbf{0 , 4}$ & 0,296 \\
$\mathbf{0 , 5}$ & 0,295 \\
$\mathbf{0 , 6}$ & 0,294 \\
$\mathbf{0 , 7}$ & 0,293 \\
$\mathbf{0 , 8}$ & 0,291 \\
$\mathbf{0 , 9}$ & 0,291 \\
\hline
\end{tabular}

Sumber: Data Tim B, 2019

\section{Hasil pengukuran kelapukan kayu}

Kayu merupakan salah satu contoh bahan organik yang rentan mengalami kerusakan, baik karena keadaan fisik lingkungan maupun karena organisme lainnya. Tentunya perlakuan terhadap tinggalan berbahan kayu yang terendam total di dalam air akan berbeda dengan yang hanya sebagian kecilnya saja yang terendam air.

Pengukuran pelapukan kayu ini dilakukan dengan menggunakan alat yang bernama pilodyn. Pilodyn memiliki bentuk seperti tabung yang pada bagian dalamnya terdapat pegas dan jarum serta terdapat alat ukur untuk mengetahui kedalaman jarum (Gambar 6). 


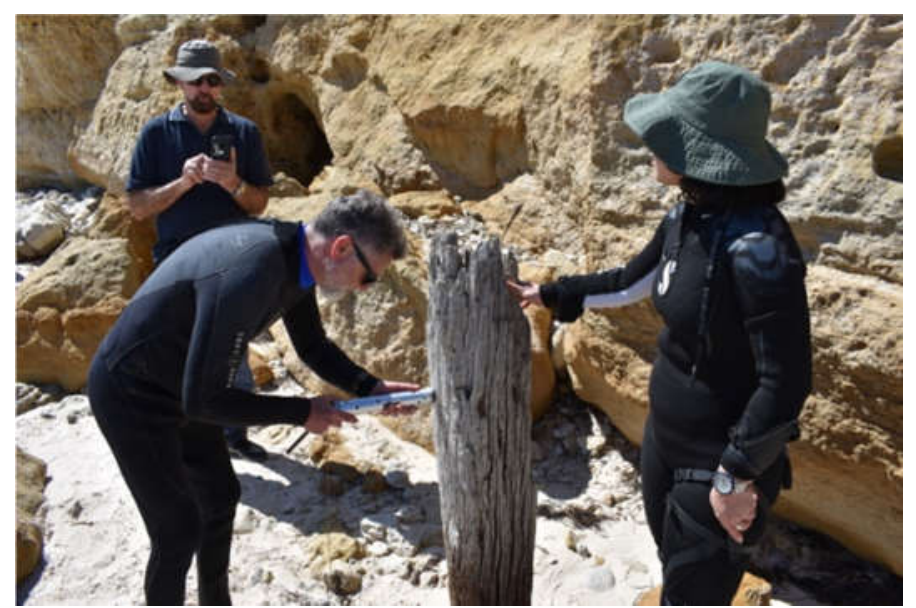

Gambar 6. Proses Pengukuran Kelapukan Kayu menggunakan Pilodyn

(Sumber: Wendy van Duivenvoorde, 2019)

Pengukuran pelapukan pada satu objek tiang dermaga dilakukan di tiga area yaitu area kering, area antara (kering ketika surut, dan basah ketika pasang), dan area basah. Selain itu, sampel pengukuran juga didasarkan pada lokasi tiang di tiga lokasi, yaitu lokasi pantai basah, lokasi pantai antara, dan lokasi pantai kering. Selain itu, pengambilan data di satu area dilakukan sebanyak dua kali. Perlakuan ini dimaksudkan untuk mengetahui perbandingan proses pelapukan kayu yang terjadi. Hasil pengukuran kelapukan kayu dapat dilihat pada tabel berikut:

Tabel 11. Hasil pengukuran pelapukan kayu Tim A

\begin{tabular}{cccc}
\hline Lokasi & Sampel no. & $\begin{array}{c}\text { Pilodyn } \\
\text { (mm) }\end{array}$ & Area \\
\hline & 1 & 10 & Kering \\
Pantai & 2 & 10 & Kering \\
Kering & 3 & 11 & Antara \\
& 4 & 12 & Antara \\
& 5 & 11 & Basah \\
& 6 & 13 & Basah \\
Pantai & 1 & 10 & Kering \\
Antara & 2 & 16 & Kering \\
& 3 & 10 & Antara \\
& 5 & 10 & Antara \\
& 6 & 12 & Basah \\
& 1 & 14 & Basah \\
Pantai & 2 & 14 & Kering \\
Basah & 3 & 15 & Kering \\
& 4 & 13 & Antara \\
& 5 & 13 & Antara \\
& 6 & 13 & Basah \\
\hline & Sumber: Data Tim A, 2019 & Basah \\
\hline
\end{tabular}


Tabel 12. Hasil Pengukuran Pelapukan Kayu Tim B

\begin{tabular}{cccc}
\hline Lokasi & Sampel no. & $\begin{array}{c}\text { Pilodyn } \\
(\mathbf{m m})\end{array}$ & Area \\
\hline & 1 & 9 & Kering \\
Pantai & 2 & 9 & Kering \\
Basah & 3 & 12 & Antara \\
& 4 & 11 & Antara \\
& 5 & 5 & Basah \\
& 6 & 15 & Basah \\
Pantai & 1 & 12 & Kering \\
Antara & 2 & 11 & Kering \\
& 3 & 15 & Antara \\
& 4 & 10 & Antara \\
& 5 & 11 & Basah \\
Pantai & 1 & 18 & Basah \\
Kering & 2 & 12 & Antara \\
& 3 & 11 & Antara \\
& 4 & 12 & Basah \\
\hline
\end{tabular}

Sumber: Data Tim B, 2019

\section{Hasil Pengukuran Korosi}

Pengukuran korosi ini dilakukan dengan menggunakan alat $\mathrm{pH}$ meter dan Eh meter. Hal pertama yang dilakukan adalah melakukan pengeboran pada besi yang untuk mendapatkan lapisan yang bersih dari karat yang kemudian sensor alat Eh meter ditempelkan yang selanjutnya dilakukan penghitungan kadar keasaman $(\mathrm{pH})$ dari besi tersebut (Gambar 7). Masing-masing tim pada pengukuran ini hanya mengambil satu sampel besi. Mengingat keberadaan besi (bekas pasak/paku) di tiang dermaga ini sangat terbatas.

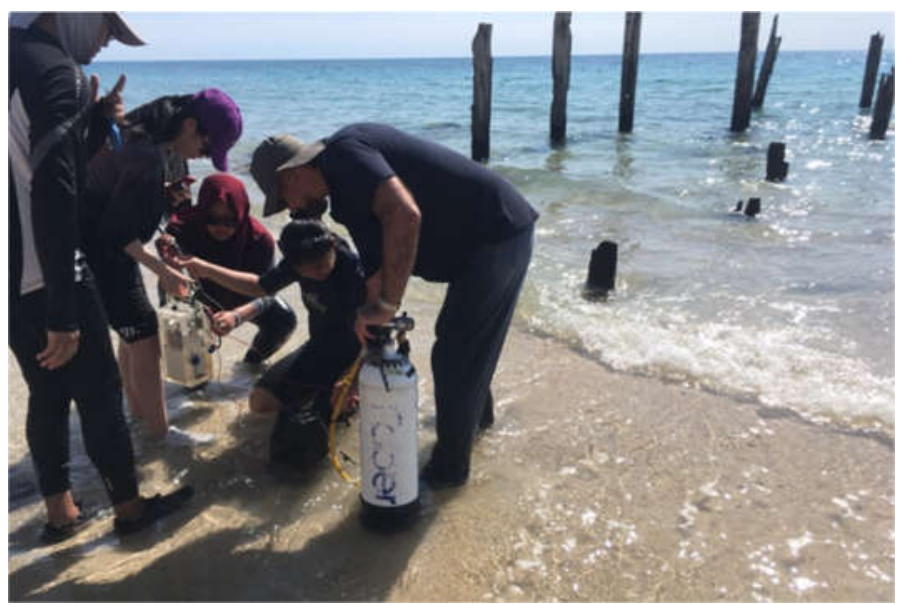

Gambar 7. Proses Pengukuran Korosi Besi (Sumber: Julia Atkinson, 2019)

Hasil pengukuran korosi dapat dilihat pada tabel berikut ini:

Tabel 13. Hasil Pengukuran Korosi Tim A

\begin{tabular}{|c|c|c|}
\hline No. Sampel & $\mathrm{pH}$ & Eh (v) \\
\hline 1 & 7,8 & $-0,333$ \\
\hline
\end{tabular}

Tabel 14. Hasil Pengukuran Korosi Tim B

\begin{tabular}{ccc}
\hline No. Sampel & pH & Eh $(\mathbf{v})$ \\
\hline $\mathbf{7}$ & 7,7 & $-0,320$ \\
\hline \multicolumn{3}{c}{ Sumber: Data Tim $B, 2019$}
\end{tabular}




\section{DISKUSI DAN PEMBAHASAN}

Hasil dari penilaian yang telah dipaparkan di atas telah mampu menunjukkan beberapa hal terkait dengan kondisi tinggalan budaya di bekas dermaga Willunga, antara lain:

\section{Kondisi Lingkungan Perairan}

Kondisi lingkungan perairan yang berada di sekitar dermaga Willunga memiliki kondisi yang sangat baik untuk perkembangan organisme. Hal ini terbukti dari empat indikator yang terdiri atas $\mathrm{DO}, \mathrm{pH}$, temperatur, dan salinitas baik yang dihitung pada pagi hari maupun siang hari. Pada penghitungan DO diketahui bahwa jumlah oksigen yang terlarut di area pantai di dermaga Willunga memiliki kadar yang cukup stabil. Pada pagi hari kadar oksigen terlarut memiliki rata-rata $6,77 \mathrm{ppm}$, sedangkan pada siang hari memiliki rata-rata 8,60 ppm. Berdasarkan pada nilai yang tercatat pada datalogger tersebut diketahui bahwa kadar oksigen yang ada di perairan dalam jumlah yang normal karena masih jauh di atas ambang batas yang bernilai $2 \mathrm{ppm}$. Nilai tersebut memungkinkan organisme air dapat hidup dengan baik di lingkungan tersebut (Salmin 2005, 22).

Data yang diperoleh dari pengukuran derajat keasaman pada perairan pantai menunjukkan bahwa pH yang ada di perairan di dermaga Willunga bersifat basa. Kedua tim memiliki angka yang hampir sama meski diukur pada waktu yang berbeda yaitu dengan rata-rata $\mathrm{pH}$ di angka 8,1. Nilai $\mathrm{pH}$ tersebut menunjukkan kondisi yang ideal bagi keberadaan organisme perairan. Berdasarkan pada keterangan yang diperoleh dari Sarry (2006 dalam Rukminasari, Nadiarti dan Awaluddin 2014, 28) menyatakan bahwa apabila lingkungan air memiliki pH dibawah 4,8 dan lebih besar dari 9,2 maka terindikasi adanya pencemaran di perairan tersebut. Hal tersebut menunjukkan bahwa $\mathrm{CO}_{2}$ lebih besar daripada $\mathrm{O}_{2}$.

Data temperatur yang dimiliki oleh kedua tim menunjukkan bahwa penghitungan yang dilakukan memiliki angka yang cukup stabil. Pada pengukuran pagi hari temperatur yang diperoleh memiliki rata-rata $15,6{ }^{\circ} \mathrm{C}$ yang perlu dicatat bahwa pada kedalaman $10 \mathrm{~cm}$ datalogger tidak merekam hasil pengukuran temperatur (dikarenakan kondisi pantai yang bergelombang), sedangkan hasil pengukuran pada siang hari menunjukkan bahwa temperatur memiliki rata-rata sekitar $15,1^{\circ} \mathrm{C}$. Nilai tersebut merupakan temperatur standar perairan pantai Australia pada musim gugur (Stobart, dkk 2016, 614).

Perubahan temperatur sangat berpengaruh pada pelarutan gas dalam air $\left(\mathrm{CO}_{2}\right.$ dan $\mathrm{O}_{2}$ ), pertumbuhan, perkembangbiakan serta persebaran dari organisme laut. Jika terjadi peningkatan temperatur maka daya pelarutan gas dalam air pun akan berkurang. Lain halnya dengan benda-benda solid yang terendam dalam air, jika terjadi peningkatan temperatur, daya pelarutan pada benda-benda itu akan ikut meningkat. Perubahan temperatur sangat berpengaruh terhadap keberadaan tiang-tiang dermaga Willunga, selain mempengaruhi lingkungan sekitarnya, efeknya juga akan sangat terasa pada material kayunya.

Data salinitas yang diperoleh dari datalogger di kedua tim menunjukkan angka stabil di 42 ppt meskipun pada hasil pengukuran di Tim B terdapat dua pengukuran yang anomali dan tidak terekam. Tidak ada perbedaan angka pengukuran di dua waktu yang berbeda. Hal ini menunjukkan bahwa kondisi perairan pantai di dermaga Willunga dalam kondisi normal yang berupa perairan asin (Fardiansyah, 2011 dalam Tobing 2019, 14).

Sementara itu, pembacaan data redoks perlu dikaitkan dengan derajat keasaman mengingat keberadaan kedua data tersebut mampu menunjukkan kondisi kimiawi suatu lingkungan. Berdasarkan pada hitungan rata-rata terhadap $\mathrm{pH}$ dan Redoks diketahui bahwa hasil yang diperoleh Tim A adalah $\mathrm{pH}$ 8,18 dan Redoks 0,30 V, sedangkan Tim B adalah pH 8,12 dan Redoks 0,29 V. Hasil pengukuran dapat dilihat pada tabel pourbaix kondisi lingkungan berikut ini: 


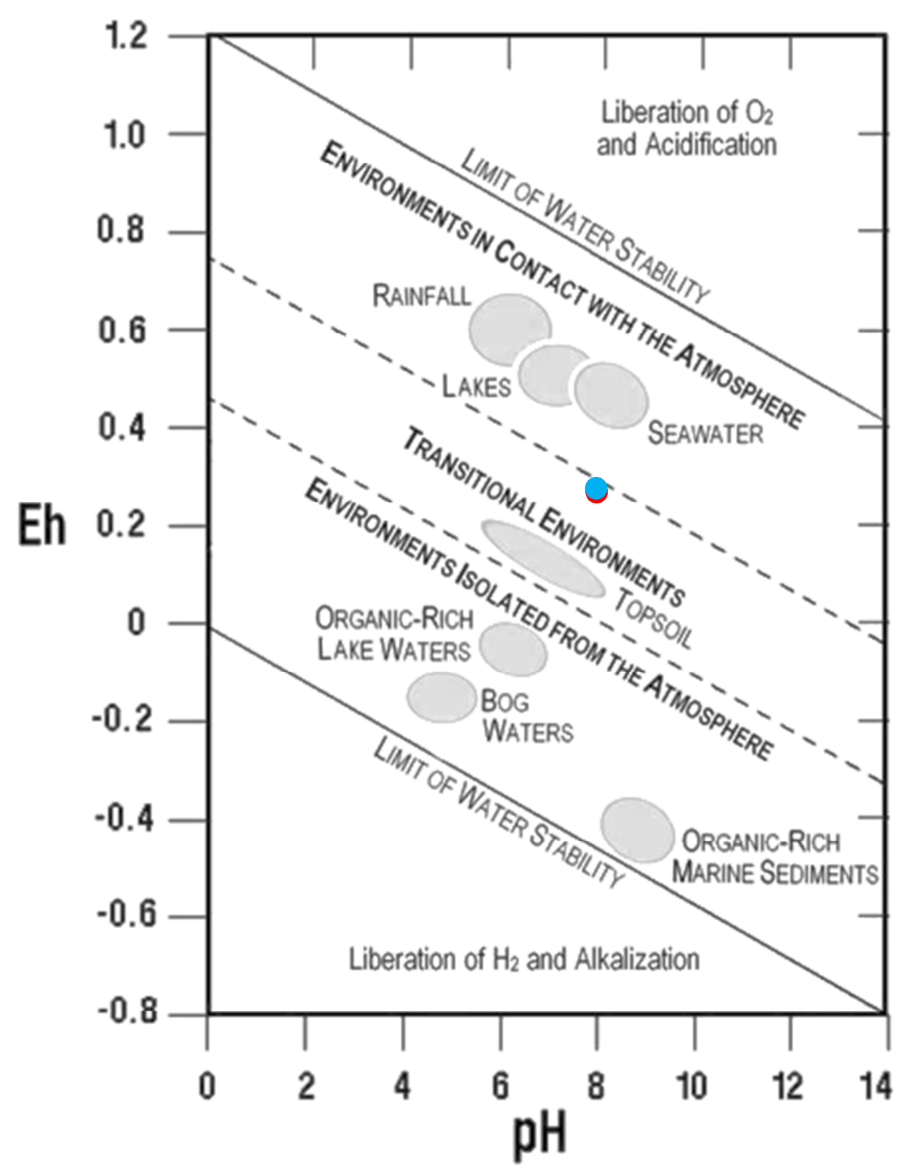

Gambar 8. Diagram Pourbaix Kondisi Lingkungan (Tim A Warna Biru, Tim B Warna Merah)

(Sumber: Data Tim A dan B. 2019)

Berdasarkan data tabel pourbaix kondisi lingkungan di atas, diketahui bahwa lingkungan yang menjadi objek kajian adalah lingkungan transisi. Kondisi lingkungan tersebut sama dengan kondisi di bekas dermaga Willunga yang merupakan area pantai.

Hasil yang diperoleh dari perekaman data permukaan air laut di sekitar pantai Willunga menunjukkan bahwa kondisi perairan tersebut normal. Dalam pengertiannya, merupakan kondisi ideal bagi pertumbuhan dan perkembangan organisme. Kondisi tersebut juga memberikan petunjuk bahwa lingkungan tersebut memungkinkan terjadinya proses degradasi kondisi tinggalan budaya dermaga Willungga yang dilakukan oleh organisme perairan.

\section{Kondisi Pelapukan Kayu}

Hasil dari pengukuran oleh dua tim menunjukkan bahwa pelapukan kayu tiang dermaga telah cukup merata baik pada area basah hingga kering. Pada pengukuran yang dilakukan oleh tim A di area kering memiliki rata-rata kedalaman $11,1 \mathrm{~mm}$, area antara memiliki rata-rata kedalaman $12 \mathrm{~mm}$, dan area basah memiliki rata-rata kedalaman 13,3 mm. Sementara itu, hasil pengukuran yang dilakukan oleh Tim B menunjukkan bahwa di area kering rata-rata kedalaman adalah 11,2 $\mathrm{mm}$, area antara memiliki rata-rata kedalaman 
12,8 mm, dan rata-rata kedalaman di area basah adalah 10,1 mm. Hasil pengukuran pilodyn yang dilakukan oleh kedua tim menunjukkan bahwa dua area memiliki kedalaman yang hampir sama yaitu di area kering dan antara, sedangkan di area basah memiliki perbedaan hasil. Perbedaan hasil tersebut menunjukkan adanya kondisi kayu yang masih memiliki perbedaan kerapatan kayu (Gambar 9).

Komponen sel-sel kayu terdiri dari dua zat utama yaitu lignin dan selulosa, lignin adalah komponen yang memberikan kekuatan pada kayu dengan mengikat komponenkomponen lainnya dan secara relatif tidak dapat dihancurkan. Berbeda dengan selulosa yang sifatnya sangat mudah hancur. Struktur sel pada material kayu melemah saat terendam air, sehingga ketika kayu terekspos oleh udara bebas permukaannya akan menegang dan menarik seluruh dinding-dinding sel secara bersamaan sehingga menyebabkan kehancuran pada dinding-dinding sel tersebut (Robinson 1998, 29). Keadaan beberapa tiang di Dermaga Willunga yang dalam waktu-waktu tertentu terendam air saat pasang dan tiba-tiba kering saat surut perlu mendapat perhatian dalam penanganan konservasinya.

Ancaman lainnya adalah adanya organisme-organisme laut yang hidup pada material kayu tersebut. Hewan-hewan tertentu seperti Limnoria sp. dan Teredo sp. sering dijumpai pada tinggalan berbahan kayu di dalam air laut. Organisme-organisme ini hidup dengan mengebor kayu sehingga menimbulkan lubang-lubang kecil. Namun karena hewanhewan ini biasanya tidak dijumpai pada perairan bersih, payau atau air dengan kadar oksigen rendah (Robinson 1998, 29) maka di Dermaga Willunga hewan-hewan ini bukan merupakan ancaman. Organisme-organisme yang akan mengancam tiang-tiang Dermaga Willunga diantaranya adalah kepiting, kerang, dan barnacle (teritip), lumut, hingga alga.

Selain sifat dari perairan, satu hal yang tidak dapat dipisahkan dari survei kelapukan kayu adalah mengetahui jenis dari kayu yang digunakan sebagai bahan. Tentunya setiap jenis kayu memiliki ketahanan dan reaksi yang berbeda ketika bersinggungan atau terendam di dalam air laut.

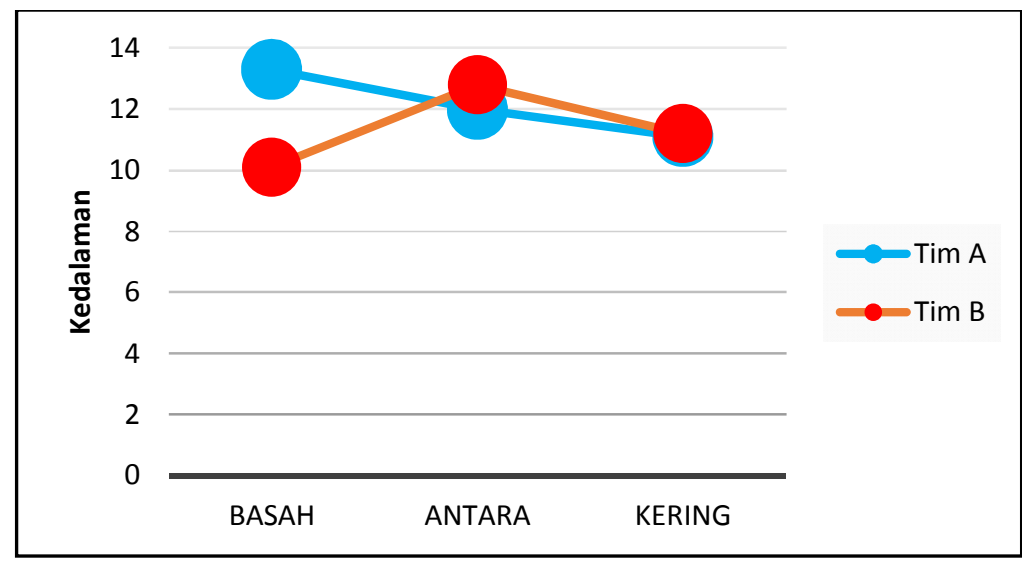

Gambar 9. Grafik Pengukuran Pilodyn

(Sumber: Data Tim A dan B, 2019)

Berdasarkan pada hasil pengukuran pilodyn tersebut menunjukkan bahwa kerapatan kayu tiang dermaga telah cukup berkurang. Anna, dkk. $(2018,166)$ menyatakan bahwa kayu memiliki kerapatan yang cukup rendah di usia muda dan seiring perkembangannya tingkat kerapatan akan semakin tinggi. Apabila kayu memiliki kerapatan yang rendah maka terindikasi bahwa kayu tersebut telah mengalami pelapukan. Tingkat pelapukan yang terjadi pada tiang dermaga Willunga ini paling tidak memiliki tiga tingkat, yaitu pelapukan tinggi yang berada di area basah karena selalu terendam oleh air laut, 
tingkat sedang yang berada di area antara dikarenakan oleh pasang surut air laut, dan tingkat cukup rendah yang berada di area kering yang sama sekali tidak terkena air laut.

\section{Kondisi Korosi Besi}

Hasil pengukuran potensi korosi oleh kedua tim pada artefak logam menunjukkan hasil yang sama. Pengukuran yang diperoleh Tim A mendapatkan $\mathrm{pH}$ dengan nilai 7,8 dan Eh sebesar -0,333 V, sedangkan Tim B memperoleh pH sebesar 7,7 dan Eh bernilai -0,320 V. Kedua hasil pengukuran tersebut kemudian dimasukkan ke dalam diagram pourbaix logam besi untuk mengetahui proses yang terjadi (Gambar 10). Berdasarkan pada diagram pourbaix logam besi tersebut diperoleh petunjuk bahwa proses korosi yang terjadi pada besi di dermaga Willunga terjadi secara aktif.

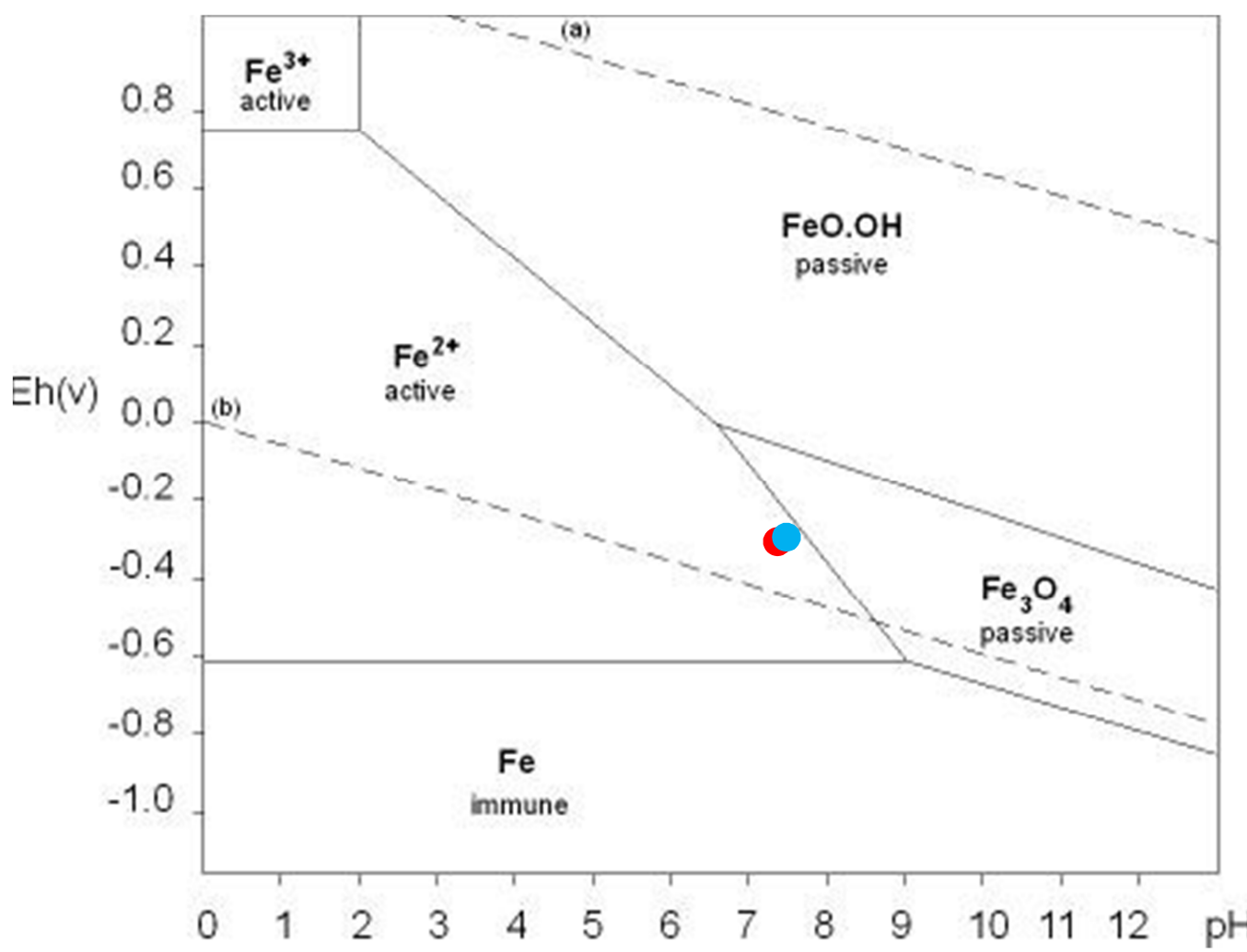

Gambar 10. Diagram Pourbaix Hasil Pengukuran Tingkat Korosi (Tim A Warna Biru, Tim B Warna Merah)

(Sumber: Data Tim A dan B, 2019)

Bagian dari dermaga Willunga yang berbahan besi adalah paku berbentuk bulat yang terdapat di seluruh tiang-tiangnya. Beberapa dari paku-paku besi tersebut terendam dalam air laut, beberapa diantaranya hanya mengalami kontak dengan air laut dalam waktu tertentu dan sisanya tidak mengalami kontak sama sekali dengan air laut. Paku-paku besi yang terendam air laut akan mengalami efek yang ditimbulkan oleh adanya biota laut dan konkresi yang menutupi permukaan besi sehingga terhalang dari kontak langsung dengan oksigen larut. Karena lapisan yang menutupi permukaan besi ini bersifat seperti membran yang agak berpori, di bawahnya kadar korosif dari garam klorida meningkat dan kondisi yang bersifat asam pun berkembang. Namun, tingkat korosinya akan cenderung tetap dan tidak berubah ketika sudah terendam beberapa tahun dalam lingkungan air laut (Carpenter $2015,668)$. 


\section{PENUTUP}

Berdasarkan pada paparan data dan pembahasan yang telah dijelaskan diperoleh hasil akhir berupa:

1. Kondisi fisik pada tinggalan budaya di bekas dermaga Willunga ini dapat diketahui dari kondisi kayu dan besi. Kondisi kayu pada bekas tiang dermaga menunjukkan telah terjadi proses pelapukan. Hal ini dikarenakan kerapatan kayu cukup rendah. Tingkat pelapukan terdiri atas tiga, yaitu pelapukan tingkat tinggi terjadi di area basah yang selalu tergenang air pantai, pelapukan tingkat sedang terjadi di area antara atau area pasang surut air, dan pelapukan tingkat cukup rendah terjadi di area kering yang tidak terkena imbas dari pasang surut air. Sementara itu, kondisi besi ketika diukur melalui $\mathrm{pH}$ dan Eh menunjukkan aktivitas korosi yang sangat aktif.

2. Ancaman yang paling terlihat pada sisa-sisa dermaga di Port Willunga adalah pelapukan yang disebabkan oleh empat hal, yaitu terendamnya beberapa bagian tiang saat permukaan laut sedang tinggi, efek sinar matahari yang sangat kuat, pergantian dari keadaan basah dan kering yang cukup cepat dan sering (karena permukaan air laut yang berubah), serta biota laut yang menempel pada tiang saat dalam kondisi terendam. Setidaknya untuk kasus di Port Willunga beberapa penyebab kerusakan seperti di atas harus diperhatikan dalam penyusunan rencana konservasi ke depannya.

\section{UCAPAN TERIMA KASIH}

Kami ucapkan terima kasih kepada Mark Staniforth dan Paddy O'Tolle dari lembaga MaP Funds; Wendy van Duivenvoorde dari Universitas Flinders; dan Jon Carpenter dan Vicki Richards dari Western Australian Museum yang telah memberikan kesempatan kepada kedua penulis untuk ikut serta dalam kegiatan tersebut. 


\section{DAFTAR PUSTAKA}

Anna, Nelly, Iskandar Z Siregar, Lina Karlinasari, dan Dede J. Sudrajat. "Keragaman Genetik Pertumbuhan Dan Hubungannya Dengan Penetrasi Pilodyn Pada Uji Provenansi-Keturunan Jabon (Neolamarkcia Cadamba (Roxb) Bosser) Di Parung Panjang, Bogor.” Jurnal Ilmu Teknologi Kayu Tropis 16, No. 2 (2018): 159-76.

Astiti, Ni Komang Ayu. "Sumber Daya Arkeologi Dalam Pembangunan Pariwisata Berkelanjutan Di Provinsi Maluku.” Jurnal Kapata Arkeologi 12, No. 1 (2016): 7-28.

Carpenter, Jon. "The Conservation of Iron Artefacts Recovered from the Marine Environment.” Dalam Shipwrecks Around The World: Revelations Of The Past, edited by Sila Tripati, 658-702. New Delhi: Delta Book World, 2015.

Dillenia, Ira, dan Luth Putu Ayu Savitri Chitra Kusuma. "Konservasi Sumberdaya Arkeologi Laut: Peluang Dan Tantangan.” Dalam Inovasi Dan Aplikasi IPTEK

Kelautan Untuk Kemandirian Dan Kejayaan Bangsa, 75-82. Surabaya: Institut Teknologi Sepuluh November, 2009.

Florian, M.L.E. "The Underwater Environment." Dalam Conservation of Marine Archaeological Object, edited by Colin Pearson, 1-20. London and Boston: Butterworths, 1987.

Hidayat, Taufik. Konservasi Material Logam Tembaga (Cu) Tinggalan Budaya Bawah Air. Universitas Islam Indonesia, 2018.

Julianto, S. Eko, dan Sulaiman. "Aplikasi Sistem Perlindungan Katodik Pada Kapal Tenggelam Sebagai Benda Cagar Budaya.” Jurnal Teknis 10,, No. 1 (2015): 37-45.

Mochtar, Agni Sesaria. "In-Situ Preservation Sebagai Strategi Pengelolaan Peninggalan Arkeologi Bawah Air Indonesia.” Jurnal Kalpataru 25, No. 1 (2016): 53-64.

Rahardjo, Supratikno. "Beberapa Permasalahan Pelestarian Kawasan Cagar Budaya Dan Strategi Solusinya.” Jurnal Konservasi Cagar Budaya Borobudur 7, No. 2 (2013): 417.

Robinson, W.S. First Aid for Underwater Finds. London: Archetype, 1998.

Rosana, Ellya. "Dinamisasi Kebudayaan Dalam Realitas Sosial.” Jurnal Al-AdYan XII, No. 1 (2017): 16-30.

Rukminasari, Nita, Nadiarti, dan Khaerul Awaluddin. "Pengaruh Derajat Keasaman (PH) Air Laut Terhadap Konsentrasi Kalsium Dan Laju Pertumbuhan Halimeda SP.” Torani: Jurnal Ilmu Kelautan Dan Perikanan 21, No. 1 (2014): 28-34.

Salmin. 2005. "Oksigen Terlarut (DO) Dan Kebutuhan Oksigen Biologi (BOD) Sebagai Salah Satu Indikator Untuk Menentukan Kualitas Perairan.” Jurnal Oseana XXX, No. 3 (2005): 21-26.

Spiridona, Petronela, dan Ion Sandu. "Conservation of Cultural Heritage: From Participation to Collaboration.” ENCATCJournal of Cultural Management and Policy 5, No. 1 (2015): 43-52.

Staniforth, Mark. The Prot Willunga Jetty. Willunga, 2016.

Stobart, B, S. Mayfield, C. Mundy, A.J. Hobday, and J.R. Hartog. "Comparison of in Situ and Satellite Sea Surface-Temperature Data from South Australia and Tasmania: How Reliable Are Satellite Data as a Proxy for Coastal Temperatures in Temperate Southern Australia?" Journal of Marine and Freshwater Research 67, No. 5 (2016): $612-25$.

Suantika, I Wayan. "Sumberdaya Arkeologi, Peranannya Bagi Pembangunan Daerah Maluku.” Jurnal Kapata Arkeologi Edisi Khusus, (2017) : 7-28.

Tobing, S. Walsen P.L. Pertumbuhan Dan Kelulushidupan Udang Vaname Litopenaeus Vanname (Boone, 1931) Pada Salinitas 5 Ppt Dengan Kepadatan Berbeda. Universitas Lampung, 2019.

McDougall Vines. Willunga District Heritage Survey. Norwood, 1997 
Yondri, Lutfi, Nina Herlina Lubis, dan Mundardjito. "Menggali Nilai-Nilai Luhur Masyarakat Masa Lalu Dari Tinggalan Budaya Materi: Studi Kasus Media Pengagungan Arwah Leluhur.” Jurnal Patanjala 8, No. 2 (2016): 139-54. 